An efficient synt hesi s of chi $r$ al i soqui nucl i di nes by Di el s- Al der reacti on usi ng Lewi s aci d cat al yst

\begin{tabular}{|l|l|}
\hline 著者 & $\begin{array}{l}\text { H RAMA Nasaf umi , KATO Yuj i , SEK Chi gusa, } \\
\text { NAKANO Hi r ot o, TAKESH TA M t suhi ro, OSH K RI } \\
\text { Nor i ko, I YODA Nasahi ko, MATSUYAMA Har uo }\end{array}$ \\
\hline $\begin{array}{l}\text { j our nal or } \\
\text { publ i cat i on t i t l e }\end{array}$ & Tet r ahedr on \\
\hline vol une & 66 \\
\hline number & 38 \\
\hline page r ange & $7618-7624$ \\
\hline year & $2010-09$ \\
\hline URL & ht t p: //hdl . handl e. net /10258/659 \\
\hline
\end{tabular}


An efficient synt hesi s of chi $r$ al i soqui nucl i di nes by Di el s- Al der reacti on usi ng Lewi s aci d cat al yst

\begin{tabular}{|l|l|}
\hline 著者 & $\begin{array}{l}\text { H RAMA Nasaf umi , KATO Yuj i , SEK Chi gusa, } \\
\text { NAKANO Hi r ot o, TAKESH TA M t suhi ro, OSH K RI } \\
\text { Nor i ko, I YODA Nasahi ko, MATSUYAMA Har uo }\end{array}$ \\
\hline $\begin{array}{l}\text { j our nal or } \\
\text { publ i cat i on t i t l e }\end{array}$ & Tet r ahedr on \\
\hline vol une & 66 \\
\hline number & 38 \\
\hline page r ange & $7618-7624$ \\
\hline year & $2010-09$ \\
\hline URL & ht t p: //hdl . handl e. net /10258/659 \\
\hline
\end{tabular}




\section{Graphical Abstract}

To create your abstract, type over the instructions in the template box below.

Fonts or abstract dimensions should not be changed or altered.

An Efficient Synthesis of Chiral Isoquinuclidines by Diels-Alder Reaction Using Lewis Acid Catalyst

Masafumi Hirama, ${ }^{a}$ Yuji Kato, ${ }^{\mathrm{a}}$ Chigusa Seki, ${ }^{\mathrm{a}}$ Hiroto Nakano, ${ }^{\mathrm{a}}$ Mitsuhiro Takeshita, ${ }^{\mathrm{b}}$ Noriko Oshikiri, Masahiko $\operatorname{Iyoda}^{\mathrm{c}}$, and Haruo Matsuyama ${ }^{\mathrm{a}, *}$
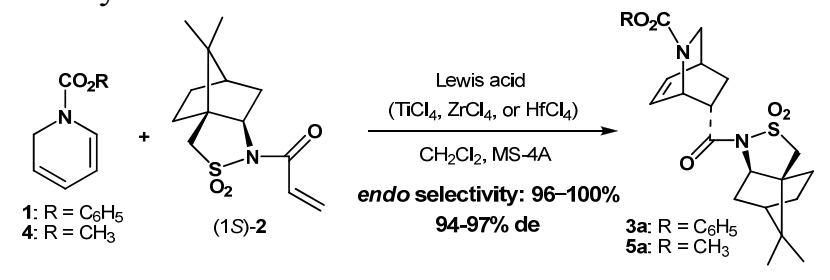

Leave this area blank for abstract info.

5a: $\mathrm{R}=\mathrm{CH}_{3}$ 


\title{
An Efficient Synthesis of Chiral Isoquinuclidines by Diels-Alder Reaction Using Lewis Acid Catalyst
}

\author{
Masafumi Hirama, ${ }^{\mathrm{a}}$ Yuji Kato, ${ }^{\mathrm{a}}$ Chigusa Seki, ${ }^{\mathrm{a}}$ Hiroto Nakano, ${ }^{\mathrm{a}}$ Mitsuhiro Takeshita, ${ }^{\mathrm{b}}$ Noriko Oshikiri, ${ }^{\mathrm{c}}$ \\ Masahiko Iyoda, ${ }^{\mathrm{c}}$ and Haruo Matsuyama ${ }^{\mathrm{a} *}$ \\ ${ }^{a}$ Department of Applied Chemistry, Faculty of Engineering, Muroran Institute of Technology, Muroran, Hokkaido 050-8585, Japan \\ ${ }^{b}$ Tohoku Pharmaceutical Univercity, 4-4-1 Komatsushima, Aoba-ku, Sendai 981-8585, Japan \\ ${ }^{c}$ Department of Chemistry, Graduate School of Science and Engineering, Tokyo Metropolitan University, Hachioji, Tokyo 192-0397, Japan
}

\section{ARTICLE INFO}

\section{ABSTRACT}

\section{Article history:}

Received

Received in revised form

Accepted

Available online

\section{Keywords:}

Alkaloid

1,2-dihydropyridine

Isoquinuclidine

Diels-Alder reaction

Lewis acid catalyst

Diastereoselectivity

\section{Introduction}

The Isoquinuclidine ring system, 2-azabicyclo[2.2.2]octane ring is common to Iboga-type indole alkaloids of which (+)catharanthine is of interest because of its eminent role as a biogenetic as well as a synthetic precursor of the antitumor alkaloids vinblastine and vincristine. ${ }^{1}$ (-)-Ibogamine and (+)catharanthine are prototypical structures of Iboga alkaloids. It is known that Ibogaine which is the medicine for alcohol dependence is bearing the ibogamine skeleton. ${ }^{2}$ Furthermore, isoquinuclidines are valuable intermediates in the synthesis of other alkaloid ${ }^{3}$ such as oseltamivir ${ }^{4}$ and in medicinal chemistry. ${ }^{5}$ The Diels-Alder (D-A) reaction between 1,2-dihydropyridines and chiral dienophiles may be the most promising method for this purpose. In the asymmetric synthesis of the 2azabicyclo[2.2.2] octane ring system, diastereoselective cycloadditions using 1,2-dihydropyridines or dienophiles attached to a chiral auxiliary have been reported. ${ }^{6}$ Recently, its catalytic enantioselective synthesis was also reported. ${ }^{7}$

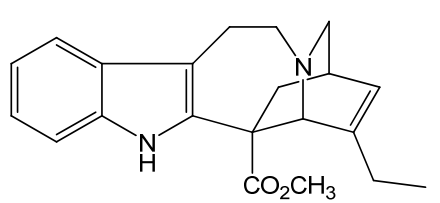

(+)-Catharanthine

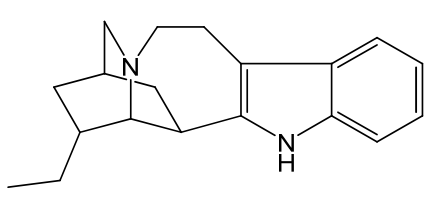

(-)-lbogamine
Figure 1. Iboga alkaloids.
We investigated the D-A cycloaddition of 1,2-dihydropyridine derivatives $^{8}$ (1-phenoxycarbonyl-1,2-dihydropyridine $\mathbf{1}$ or 1 methoxycarbonyl-1,2-dihydropyridine 4) with $N$-acryloyl-(1S)2,10-camphorsultam (1S)-2 (or $N$-acryloyl-(1R)-2,10camphorsultam (1R)-2) ${ }^{9}$ in the presence of a Lewis acid. ${ }^{10}$ Though it is reported that 1,2-dihydropyridine is unstable for Lewis acid, our reaction system afforded chiral isoquinuclidines in good yields with high diastereoselectivity. The absolute stereochemistry of the endo-cycloaddition products was determined by conversion of $(1 S)$-5a to the known product $(7 S)$ 6. ${ }^{11} \mathrm{We}$ describe the detail of the very useful method for synthesis of the chiral isoquinuclidines.

\section{Results and discussion}

\subsection{Diels-Alder reaction of 1-phenoxycarbonyl-1,2-dihydro- pyridine 1 with 1S-2 (or 1R-2)}

We initially tested the cycloaddition of 1-phenoxycarbonyl 1,2-dihydropyridine 1 with $N$-acryloyl-(1S)-2,10-camphorsultam 2. The reaction was carried out under reflux conditions in toluene to give the corresponding cycloaddition products 3 (endo $3 \mathbf{a}:$ exo $\mathbf{3 b}=57: 43$ ) in $82 \%$ yield with $38 \%$ d.e. of endo adduct $3 \mathbf{a}$ (Table 1, Entry 15).

Thus, the cycloaddition of $\mathbf{1}$ with (1S)-2 under reflux conditions showed low diastereoselectivity. Next, the cycloadditions of 1 with (1S)-2 in the presence of various Lewis acids such as titanium tetrachloride $\left(\mathrm{TiCl}_{4}\right)$, zirconium tetrachloride $\left(\mathrm{ZrCl}_{4}\right)$ 
Table 1. Cycloaddition of 1,2-dihydropyridine 1 with dienophile (1S)-2 or (1R)-2 in the presence of Lewis acid.

\begin{tabular}{|c|c|c|c|c|c|c|c|c|}
\hline Entry & $\begin{array}{c}\text { Diene } \\
\text { (molar equiv) } \\
\end{array}$ & $\begin{array}{c}\text { Dienophile } \\
\text { (molar equiv) }\end{array}$ & $\begin{array}{l}\text { Lewis acid } \\
\text { (molar equiv) }\end{array}$ & $\begin{array}{l}\text { Temp } \\
/{ }^{\circ} \mathrm{C} \\
\end{array}$ & Time & $\begin{array}{l}\text { Yield a) } \\
1 \%\end{array}$ & $\begin{array}{c}\text { endo : exo } \\
\mathbf{3 a}: \mathbf{3 b}\end{array}$ & $\begin{array}{r}\% \text { d.e. } \mathrm{b}) \\
\text { of endo } 3 \mathrm{a}\end{array}$ \\
\hline 1 & $1(2)$ & $(1 S)-2(1)$ & $\mathrm{TiCl}_{4}(1.3)$ & -78 & 24 & 99 & $96:$ & 94 (1S) \\
\hline $2^{c)}$ & $1(2)$ & $(1 S)-2(1)$ & $\mathrm{TiCl}_{4}(2)$ & $-78 \rightarrow \mathrm{rt}$ & 48 & $66(28)$ & $98:$ & $96(1 S)$ \\
\hline 3 & $1(2)$ & $(1 S)-2(1)$ & $\mathrm{TiCl}_{4}(1)$ & 0 & 24 & $30(46)$ & $94:$ & $93(1 S)$ \\
\hline $4^{d)}$ & $1(2)$ & $(1 S)-2(1)$ & $\mathrm{ZrCl}_{4}(2)$ & $\mathrm{rt}$ & 24 & 78 (15) & $98:$ & $96(1 S)$ \\
\hline 5 & $1(2)$ & $(1 S)-2(1)$ & $\mathrm{HfCl}_{4}(2)$ & -78 & 24 & $45(34)$ & $98: 2$ & $98(1 S)$ \\
\hline 6 & $1(2)$ & $(1 S)-2(1)$ & $\mathrm{HfCl}_{4}(2)$ & $\mathrm{rt}$ & 24 & $89(6)$ & $99: 1$ & $97(1 S)$ \\
\hline 7 & $1(2)$ & $(1 S)-2(1)$ & $\mathrm{SnCl}_{4}(1.3)$ & -78 & 24 & $12(69)$ & $99: 1$ & $82(1 S)$ \\
\hline 8 & $1(2)$ & $(1 S)-2(1)$ & $\mathrm{Sc}(\mathrm{OTf})_{3}(1)$ & -78 & 24 & $60(18)$ & 99 : & $68(1 S)$ \\
\hline 9 & $1(2)$ & $(1 S)-2(1)$ & $\mathrm{Ti}(i-\mathrm{PrO})_{2} \mathrm{Cl}_{2}(2)$ & $\mathrm{rt}$ & 24 & $34(60)$ & $100:$ & $94(1 S)$ \\
\hline 10 & $1(2)$ & $(1 R)-2(1)$ & $\mathrm{TiCl}_{4}(1)$ & -78 & 24 & 98 & 99 : & $96(1 R)$ \\
\hline 11 & $1(2)$ & $(1 R)-2(1)$ & $\mathrm{TiCl}_{4}(1)$ & 0 & 24 & 19 & $97: 3$ & $89(1 R)$ \\
\hline $12^{d)}$ & $1(2.5)$ & $(1 R)-2(1)$ & $\mathrm{ZrCl}_{4}(2)$ & $\mathrm{rt}$ & 24 & $78(15)$ & $99: 1$ & $92(1 R)$ \\
\hline 13 & $1(2.5)$ & $(1 R)-2(1)$ & $\mathrm{HfCl}_{4}(2)$ & $\mathrm{rt}$ & 24 & 97 & 99 : & $94(1 R)$ \\
\hline $14^{\text {c) }}$ & $1(2)$ & $(1 R)-2(1)$ & $\mathrm{Ti}(i-\mathrm{PrO})_{2} \mathrm{Cl}_{2}(1.5)$ & $-78 \rightarrow \mathrm{rt}$ & 48 & $30(54)$ & $100: 0$ & $98(1 R)$ \\
\hline $15^{\mathrm{e})}$ & $1(2)$ & $(1 S)-2(1)$ & $\longrightarrow$ & reflux & 48 & $82(5)$ & $57: 43$ & $38(1 S)$ \\
\hline $16^{\mathrm{e})}$ & $1(3)$ & $(1 R)-2(1)$ & $\longrightarrow$ & reflux & 48 & $>99$ & $78: 22$ & $33(1 R)$ \\
\hline
\end{tabular}

a Isolated yield. Recovery of 2 is shown in parentheses. ${ }^{\mathrm{b}}$ Diastereomeric excess (\% d.e.) was determined by HPLC analysis using a TOSOH TSK-GEL Silica-60; $1 \%$ ethanol $/ n$-hexane, flow rate $1.0 \mathrm{~mL} / \mathrm{min}, R t=45 \mathrm{~min}$ (major), $49 \mathrm{~min}$ (minor). ${ }^{\mathrm{C}} \mathrm{At}-78^{\circ} \mathrm{C}$ for $24 \mathrm{~h}$ then at $\mathrm{rt}$ for $24 \mathrm{~h}$.

${ }^{\mathrm{d}}$ Dropwise addition of $1 .{ }^{\mathrm{e}}$ Refluxing in toluene.

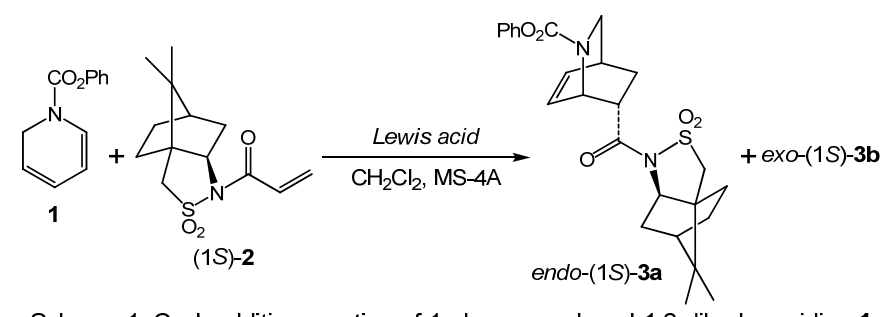

Scheme 1. Cycloaddition reaction of 1-phenoxycarbonyl-1,2-dihydropyridine 1 with $N$-acryloyl (1S)-2,10-camphorsultam 2 in the presence of Lewis acid.

and hafnium tetrachloride $\left(\mathrm{HfCl}_{4}\right)$ as a catalyst were investigated. The results of the cycloaddition in the presence of a Lewis acid are summarized in Table 1 . The cycloaddition of 1 with $(1 S)-2$ in the presence of 1.3 equiv. of $\mathrm{TiCl}_{4}$ was carried out at $-78^{\circ} \mathrm{C}$ in dichloromethane to afford the endo-cycloaddition product $3 \mathbf{a}$ in $99 \%$ yield with $94 \%$ d.e. (Table 1, Entry 1 ). The cycloaddition of 1 with (1S)-2 using 2 equiv. of $\mathrm{TiCl}_{4}$ was carried out at $-78^{\circ} \mathrm{C}$ for 24 hours, followed by reaction at room temperature for 24 hours to give the endo-cycloaddition product 3a in $66 \%$ yield with $96 \%$ d.e. (Entry 2). When the cycloaddition of 1 with $(1 S)-2$ in the presence of $\mathrm{TiCl}_{4}$ was run at $0{ }^{\circ} \mathrm{C}$ or at room temperature, the reaction did not proceed well and the unknown compound was obtained. The yield of $\mathbf{3 a}$ was $30 \%$ at $0{ }^{\circ} \mathrm{C}$ (Entry 3 ). In order to determine the unknown compound, $N$-3-chloropropanoyl (1S)2,10-camphorsultam ${ }^{12}$ was prepared (Scheme 2) and the ${ }^{1} \mathrm{H}$ NMR spectra of the authentic compound and the by-product were identical. Therefore, in a case of using $\mathrm{TiCl}_{4}$, it is necessary to keep the low reaction temperature $\left(-78^{\circ} \mathrm{C}\right)$.

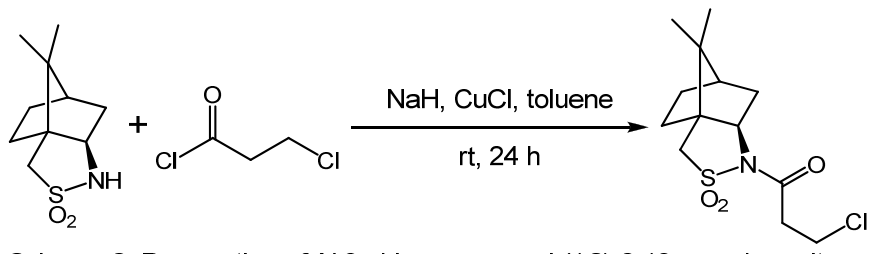

Scheme 2. Preparation of N-3-chloropropanoyl (1S)-2,10-camphorsultam.

The reactivity of several Lewis acids for the asymmetric cycloaddition of 1-phenoxycarbonyl 1,2-dihydropyridine 1 with (1S)-2 was also investigated. Lewis acids of the group IV metals such as $\mathrm{TiCl}_{4}, \mathrm{ZrCl}_{4}$, and $\mathrm{HfCl}_{4}$ have been found to be effective catalysts for this cycloaddition system. In the presence of these catalysts, the cycloadditions of 1 with (1S)-2 produced the endocycloaddition product (1S)-3a in good yields, and the diastereoselectivity of the endo-cycloaddition product was excellent as shown in Table 1; for example, $\mathrm{TiCl}_{4}(94 \%$ d.e.) (Table 1, Entry 1), $\mathrm{ZrCl}_{4}\left(96 \%\right.$ d.e.) (Entry 4), and $\mathrm{HfCl}_{4}(97 \%$ d.e.) (Entry 6). When $\mathrm{ZrCl}_{4}$ was employed, dropwise addition of diene 1 gave better result (78\% yield) (Entry 4 ). $\mathrm{HfCl}_{4}$ was the most useful Lewis acid and the cycloaddition reaction smoothly proceeded at room temperature. (Entry 6). When the Lewis acid except for the described above was used as a catalyst, the cycloaddition did not proceed well. The cycloaddition of $\mathbf{1}$ with (1S)-2 using tin tetrachloride $\left(\mathrm{SnCl}_{4}\right)$ as a Lewis acid was carried out at $-78{ }^{\circ} \mathrm{C}$ to give the endo-cycloaddition product $(1 S)$-3a in $12 \%$ yield with $82 \%$ d.e. (Entry 7 ). The reactivity of $\mathrm{SnCl}_{4}$ was very low, but the diastereoselectivity of (1S)-3a was relatively high. The cycloaddition of $\mathbf{1}$ with (1S)-2 using scandium trifluoromethanesulfonate $\left[\mathrm{Sc}(\mathrm{OTf})_{3}\right]$ as a Lewis acid proceeded and gave endo-cycloaddition product 3a in moderate yield (60\%), but the diastereoselectivity was low (68\% d.e.) (Entry 8$)$. The cycloaddition of 1 with $(1 S)-2$ using $\mathrm{Ti}(i-\mathrm{PrO})_{2} \mathrm{Cl}_{2}$ gave low yield of (1S)-3a at room temperature $(34 \%$ yield $)$, but the diastereoselectivity was high $(94 \%$ d.e.) (Entry 9$)$.

The cycloaddition reaction of 1-phenoxycarbonyl 1,2dihydropyridine 1 with $(1 R)-\mathbf{2}$, which is an enantiomer of $(1 S)$-2, was carried out and the results are summarized in Table 1 . In the presence of $\mathrm{TiCl}_{4}, \mathrm{ZrCl}_{4}$, and $\mathrm{HfCl}_{4}$, the cycloadditions of $\mathbf{1}$ with $(1 R)-2$ produced the endo-cycloaddition product $(1 R)$-3a in

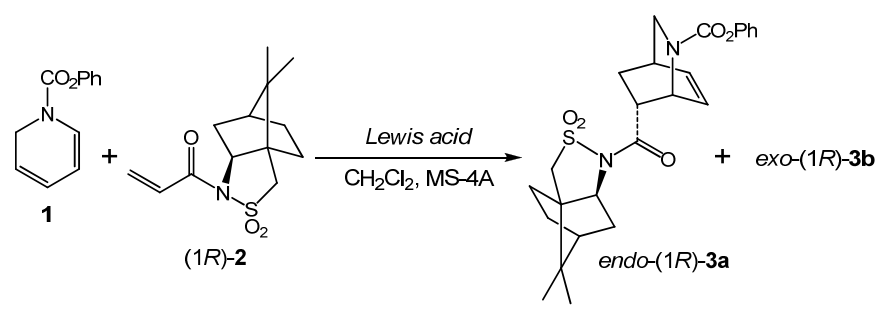

Scheme 3. Cycloaddition reaction of 1-phenoxycarbonyl-1,2-dihydropyridine 1 with $N$-acryloyl (1R)-2,10-camphorsultam $\mathbf{2}$ in the presence of Lewis acid. 
Table 2. Cycloaddition of 1,2-dihydropyridine $\mathbf{4}$ with dienophile 2 in the presence of Lewis acid.

\begin{tabular}{|c|c|c|c|c|c|c|c|c|}
\hline Entry & $\begin{array}{c}\text { Diene } \\
\text { (molar equiv) } \\
\end{array}$ & $\begin{array}{c}\text { Dienophile } \\
\text { (molar equiv) }\end{array}$ & $\begin{array}{l}\text { Lewis acid } \\
\text { (molar equiv) }\end{array}$ & $\begin{array}{l}\text { Temp } \\
/{ }^{\circ} \mathrm{C} \\
\end{array}$ & $\begin{array}{c}\text { Time } \\
/ \mathrm{h}\end{array}$ & $\begin{array}{l}\text { Yield }^{\text {a) }} \\
1 \% \\
\end{array}$ & $\begin{array}{c}\text { endo: exo } \\
\mathbf{5 a}: \mathbf{5 b} \\
\end{array}$ & $\begin{array}{r}\% \text { d.e. b) } \\
\text { of endo } 5 a \\
\end{array}$ \\
\hline 1 & $4(2.2)$ & $(1 S)-2(1)$ & $\mathrm{TiCl}_{4}(1.5)$ & -78 & 24 & $63(31)$ & 100: 0 & $95(1 S)$ \\
\hline 2 & $4(4)$ & $(1 S)-2(1)$ & $\mathrm{TiCl}_{4}(2)$ & -78 & 24 & $71(27)$ & $100: 0$ & $>99$ (1S) \\
\hline 3 & $4(2)$ & $(1 S)-2(1)$ & $\mathrm{ZrCl}_{4}(1)$ & $\mathrm{rt}$ & 24 & $5(81)$ & $\longrightarrow$ & $\longrightarrow$ \\
\hline 4 & $4(2)$ & $(1 S)-2(1)$ & $\mathrm{HfCl}_{4}(1.5)$ & 0 & 24 & $17(63)$ & $100: 0$ & $98(1 S)$ \\
\hline 5 & $4(2)$ & $(1 S)-2(1)$ & $\mathrm{HfCl}_{4}(2)$ & $\mathrm{rt}$ & 24 & $87(12)$ & $100: 0$ & $98(1 S)$ \\
\hline 6 & $4(2)$ & $(1 R)-2(1)$ & $\mathrm{TiCl}_{4}(1)$ & -78 & 24 & $26(73)$ & $97: 3$ & $97(1 R)$ \\
\hline 7 & $4(4)$ & $(1 R)-2(1)$ & $\mathrm{TiCl}_{4}(2)$ & -78 & 24 & $91(9)$ & $100: 0$ & $>99(1 R)$ \\
\hline 8 & $4(2)$ & $(1 R)-2(1)$ & $\mathrm{ZrCl}_{4}(2)$ & $\mathrm{rt}$ & 24 & $11(41)$ & $\longrightarrow$ & $\longrightarrow$ \\
\hline 9 & $4(2)$ & $(1 R)-2(1)$ & $\mathrm{HfCl}_{4}(2)$ & $\mathrm{rt}$ & 24 & $52(36)$ & $100: 0$ & $98(1 R)$ \\
\hline $10^{c)}$ & $4(3)$ & $(1 S)-2(1)$ & $\longrightarrow$ & reflux & 24 & $89(9)$ & $60: 40$ & $63(1 S)$ \\
\hline $11^{c)}$ & $4(3)$ & $(1 R)-2(1)$ & $\longrightarrow$ & reflux & 24 & 95 & $67: 33$ & $65(1 R)$ \\
\hline
\end{tabular}

alsolated yield. Recovery of $\mathbf{2}$ is shown in parentheses. ${ }^{\mathrm{b}}$ Diastereomeric excess (\% d.e.) was determined by HPLC analysis using a TOSOH TSK-GEL Silica-60; $1 \%$ ethanol $/ n$-hexane, flow rate $1.0 \mathrm{~mL} / \mathrm{min}, R t=60 \mathrm{~min}$ (major), $63 \mathrm{~min}$ (minor). ${ }^{\mathrm{C}}$ Refluxing in toluene.

good yields, and the diastereoselectivity of the endocycloaddition product $(1 R)$-3a was excellent as shown in Table 1 ; for example, $\mathrm{TiCl}_{4}(96 \%$ d.e.) (Table 1, Entry 10$), \mathrm{ZrCl}_{4}(92 \%$ d.e.) (Table 1, Entry 12), and $\mathrm{HfCl}_{4}(94 \%$ d.e.) (Table 1, Entry 13). On the other hand, the cycloaddition of 1 with $(1 R)-2$ using $\mathrm{Ti}(i-\mathrm{PrO})_{2} \mathrm{Cl}_{2}$ was undergone at $-78{ }^{\circ} \mathrm{C}$ for 24 hours, followed by reaction at room temperature for 24 hours to afford the endocycloaddition product $(1 R)-3 \mathbf{a}$ in $30 \%$ yield with $98 \%$ d.e. Though the reactivity of $\mathrm{Ti}(i-\mathrm{PrO})_{2} \mathrm{Cl}_{2}$ was low under the conditions, the stereoselectivity of endo $(1 R)$-3a was high $(98 \%$ d.e.) (Table 1, Entry 14).

\subsection{Diels-Alder reaction of 1-methoxycarbonyl-1,2-dihydro- pyridine 4 with $1 S-2$ (or 1R-2)}

Next, we investigated the reaction of 1-methoxycarbonyl-1,2dihydropyridine $\mathbf{4}$ and $N$-acryloyl 2,10-camphorsultams 2.

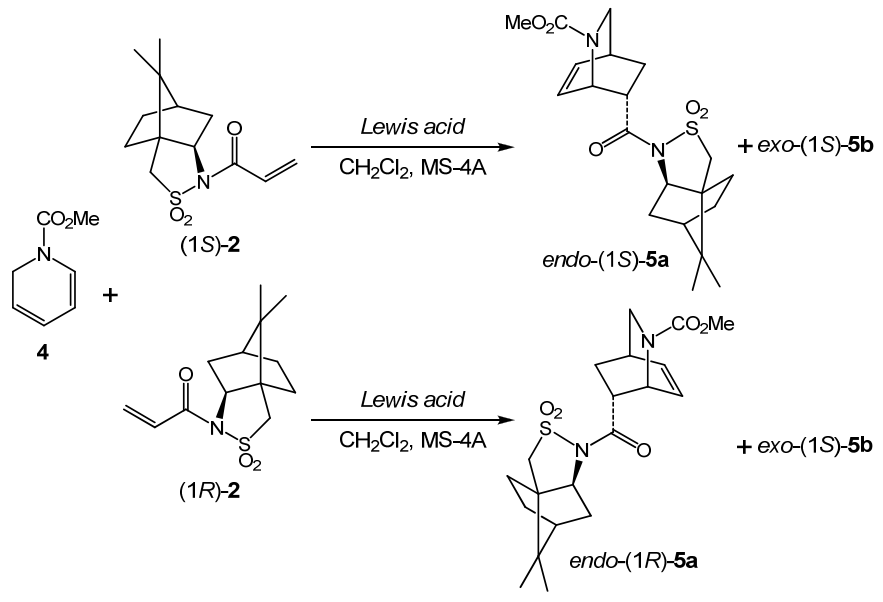

Scheme 4. Cycloaddition reaction of 1-methoxycarbonyl-1,2-dihydropyridine 4 with $N$-acryloyl (1S or $1 R$ )-2,10-camphorsultam 2 in the presence of Lewis acid.

Firstly, the cycloaddition of 1-methoxycarbonyl-1,2dihydropyridine 4 with $N$-acryloyl (1S)-2,10-camphorsultam 2 [or $N$-acryloyl (1R)-2,10-camphorsultam 2] was carried out under reflux in toluene. As the results are shown in Table 2, the reactions of $\mathbf{4}$ with $\mathbf{2}$ proceeded smoothly to give cycloaddition products endo-(1S)-5a and exo-(1S)-5b (endo-5a: exo-5b = $60: 40$ ), but the diastereoselectivity of the cycloaddition products (1S)-5 was not high (63\% d.e.) (Table 2, Entry 10). Next, Lewis acids such as $\mathrm{TiCl}_{4}, \mathrm{ZrCl}_{4}$ and $\mathrm{HfCl}_{4}$ were employed in the cycloaddition reaction of 1-methoxycarbonyl-1,2-dihydropyridine 4 with 2 . The results are summarized in Table 2. Although 1-methoxycarbonyl-1,2-dihydropyridine $\mathbf{4}$ is unstable for Lewis acid than 1-phenoxycarbonyl-1,2-dihydropyridine 1, the cycloaddition reaction in the presence of Lewis acid proceeded smoothly. The cycloaddition of 2.2 equiv of 1 methoxycarbony-1,2-dihydropyridine 4 and $N$-acryloyl (1S)camphorsultam (1S)-2 in the presence of 1.5 equiv. of $\mathrm{TiCl}_{4}$ was carried out at $-78{ }^{\circ} \mathrm{C}$ to give the endo-cycloaddition product $(1 S)$ 5 (endo-5a: exo-5b $=100: 0)$ in $63 \%$ yield with $95 \%$ d.e. (Entry 1). In the presence of 2 equiv. of $\mathrm{TiCl}_{4}$, the D-A reaction of 4 equiv of 4 with (1S)-2 were carried out at $-78{ }^{\circ} \mathrm{C}$ to give the endo-cycloaddition product (1S)-5a in $71 \%$ yield with $99 \%$ d.e. (Entry 2). On the other hand, the cycloaddition of 4 with (1S)-2 using $\mathrm{ZrCl}_{4}$ as a Lewis acid could hardly undergo, and $\mathrm{N}$-acryloyl (1S)-camphorsultam (1S)-2 was recovered (81\%) (Entry 3$)$. The cycloaddition in the presence of $\mathrm{HfCl}_{4}$ was subsequently investigated at $0{ }^{\circ} \mathrm{C}$ or room temperature. In the $\mathrm{D}-\mathrm{A}$ reaction of 4 with (1S)-2 at $0{ }^{\circ} \mathrm{C}$, the yield of 5 a was $17 \%$ and $63 \%$ of the $N$ acryloyl (1S)-camphorsultam (1S)-2 was recovered (Entry 4). In the presence of 2 equiv. of $\mathrm{HfCl}_{4}$, the D-A reaction of 4 with (1S)-2 was carried out at room temperature to give the endocycloaddition product (1S)-5a in $87 \%$ yield with $98 \%$ d.e. (Entry $5)$. The D-A reaction of 1-methoxycarbonyl-1,2-dihydropyridine 4 with $N$-acryloyl (1R)-2,10-camphorsultam (1R)-2, which is enantiomer of $N$-acryloyl (1S)-2,10-camphorsultam $(1 S)$-2, was also carried out in the presence of $\mathrm{TiCl}_{4}, \mathrm{ZrCl}_{4}$ and $\mathrm{HfCl}_{4}$. In the presence of 1 equiv. of $\mathrm{TiCl}_{4}$, the D-A reaction was carried out at $-78{ }^{\circ} \mathrm{C}$ to give the endo-cycloaddition product $(1 R)-5 a$ in $26 \%$ yield and the diastereomeric excess was high $(97 \%$ d.e. $)$, and $73 \%$ of the camphorsultam 2 was recovered (Entry 6). In the presence of 2 equiv. of $\mathrm{TiCl}_{4}$, the D-A reaction of $\mathbf{4}$ with $(1 R)-2$ proceeded smoothly and endo $(1 R)-5$ a was obtained in $91 \%$ yield with $99 \%$ d.e. (Entry 7 ). In the presence of 2 equiv. of $\mathrm{HfCl}_{4}$, the D-A reaction of 4 with (1R)-2 was carried out at room temp to give the endo-cycloaddition product $(1 R)-5 \mathrm{a}$ in $52 \%$ yield with $98 \%$ d.e. (Entry 9). However, when $\mathrm{ZrCl}_{4}$ as a Lewis acid was employed, the D-A reaction of 4 with $(1 R)-2$ did not proceed smoothly (Entry 8).

\subsection{Determination of absolute stereochemistry of isoquinuclidine: estimation of plausible reaction mechanism}

The absolute stereochemistry of the endo-cycloaddition products $(1 S)-\mathbf{5 a}$ and $(1 R)-\mathbf{5 a}$ were determined as follows. For the assignment of the endo-cycloaddition product $(1 S)-5 \mathbf{a}$, the product was converted to the known $(1 S, 4 R, 7 S)$-methyl ester 
6. ${ }^{11}$ Thus, the reaction of the product $(1 S)-5 a$ with lithium methoxide as a base in $\mathrm{MeOH}-\mathrm{THF}$ afforded (7S)-methyl ester 6 in moderate yield (54\%). Similarly, the product $(1 R)-5$ a was converted to the known $(1 R, 4 S, 7 R)$-methyl ester 6 in $49 \%$ yield (Scheme 5). ${ }^{11}$ According to the stereochemistry of (7S)-6, the absolute configuration of azabicyclo[2.2.2] octane derivative (1S)$3 a$, which was obtained from the reaction of $N$-acryloyl (1S)2,10-camphorsultam 2 with 1-phenoxycarbonyl-1,2-dihydropyridine 1 , has been also established to be $(1 S, 4 R, 7 S)$. On the other hand, the absolute configuration of azabicyclo[2.2.2]octane derivative $(1 R)$-3a which was obtained from the reaction of $N$ acryloyl $(1 R)$-2,10-camphorsultam 2 with 1-phenoxycarbonyl1,2-dihydropyridine 1 , has been established to be $(1 R, 4 S, 7 R)$.

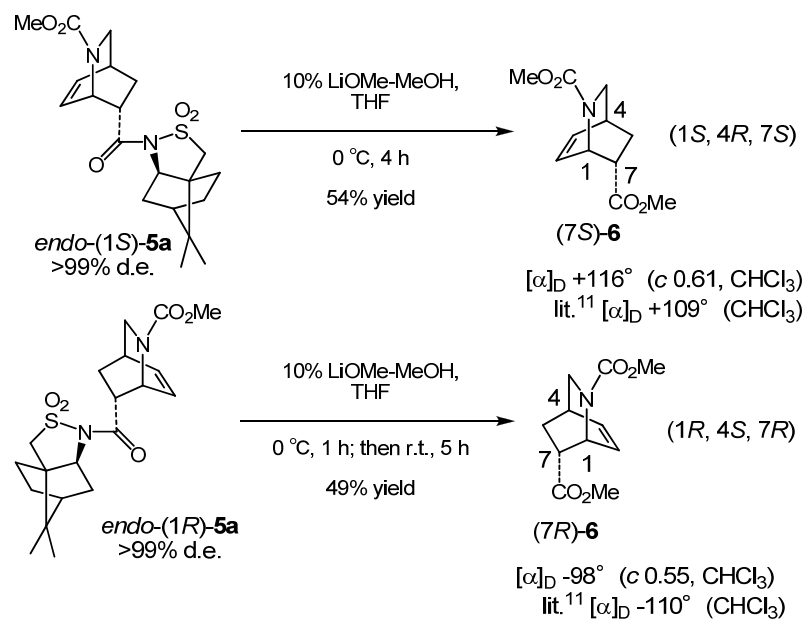

Scheme 5. Determination of absolute configuration of Diels-Alder adduct 5a

We estimated the plausible reaction mechanism of the D-A cycloaddition reaction of 1,2-dihydropyridine (1 or 4) with $\mathrm{N}$ acryloyl (1S)-2,10-camphorsultam (1S)-2 in the presence of a Lewis acid. Because of the complex formation of $\mathrm{N}$-acryloyl (1S)-2,10-camphorsultam (1S)-2 with Lewis acid such as $\mathrm{TiCl}_{4}$, the complex structure may be fixed tightly. Attack of the diene to the $(1 S)$-2-metal complex was then postulated to occur $\pi$-facial selectivity to give (1S)-3a (or (1S)-5a). Due to the bulky camphorsultam group in (1S)-2-metal complex, the attack of the diene from $S i$ face may be hard.

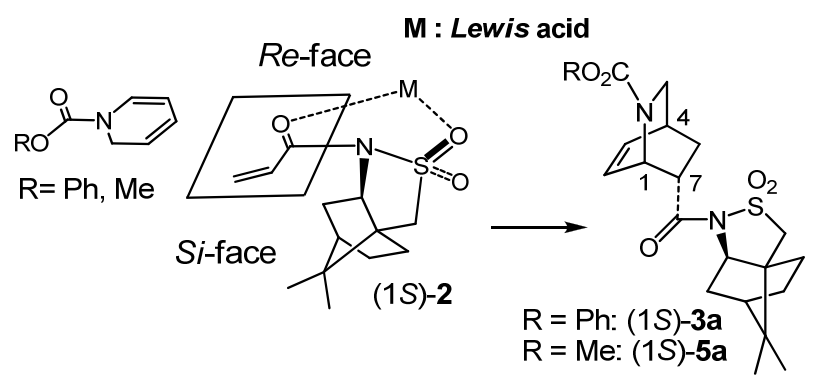

Figure 2. Plausible reaction course of 1,2-dihydropyridine with (1S)-2 in the presence of Lewis acid.

\subsection{Complex formation of dienophiles with Lewis acid}

The X-ray diffraction analysis of the crystalline complex of $\mathrm{N}$ crotonoyl (1S)-2,10-camphorsultam with $\mathrm{TiCl}_{4}$ is reported by W. Oppolzer et al. ${ }^{14}$ The complex shows a chelation structure of the carbonyl oxygen-atom and the $\mathrm{SO}_{2}$ oxygen-atom with $\mathrm{TiCl}_{4}$. In order to study the complex formation of $\mathrm{N}$-acryloyl (1S)-2,10camphorsultam with a Lewis acid, ${ }^{1} \mathrm{H}$ NMR spectra and ${ }^{13} \mathrm{C}$
NMR spectra of the mixture of $N$-acryloyl (1S)-2,10camphorsultam 2 and Lewis acids such as $\mathrm{TiCl}_{4}, \mathrm{ZrCl}_{4}$ and $\mathrm{HfCl}_{4}$ were measured and the results are summarized in Table 3. Firstly, ${ }^{1} \mathrm{H}$ NMR spectrum and ${ }^{13} \mathrm{C}$ NMR spectrum of the noncoordinated $N$-acryloyl (1S)-2,10-camphorsultam (1S)-2 (A) were measured in $\mathrm{CDCl}_{3}$ (Table 3, compound A) The crystalline complex of $N$-acryloyl (1S)-2,10-camphorsultam 2 with $\mathrm{TiCl}_{4}(1$ molar-equiv.) was also prepared according to the Oppolzer's procedure ${ }^{14}$, and its ${ }^{1} \mathrm{H}$ NMR spectrum and ${ }^{13} \mathrm{C}$ NMR spectrum were measured in $\mathrm{CD}_{2} \mathrm{Cl}_{2}$ (Table 3, compound $\mathbf{A}$ ). In the ${ }^{1} \mathrm{H}$ NMR spectrum of $\mathbf{B}$ the signals of $C(13)$ and $C(11)$ were not observed. However, the signals of $\mathrm{C}(13)$ and $\mathrm{C}(11)$ of the complex of $N$-crotonoyl (1S)-2,10-camphorsultam and $\mathrm{TiCl}_{4}$ which was prepared by Oppolzer were observed and assigned. The chemical shifts of the Oppolzer's complex are as follows: C(10) 53.07 ppm, C(2) 66.14 ppm, C(12) 119.93 ppm, C(13) $159.80 \mathrm{ppm}$, and $\mathrm{C}(11) 172.04 \mathrm{ppm}$. The complex $\mathbf{B}$ was unstable in the air and in the solution. As time went by, the complex was decomposed and $\mathrm{HCl}$ was generated. The ${ }^{1} \mathrm{H}$ NMR of the complex was measured every few hours. Then the signals of the chlorinated (1S)-2 (Scheme 2) were appeared in the spectrum of the crystalline complex. In the case of $\mathrm{ZrCl}_{4}$ or $\mathrm{HfCl}_{4}$, the NMR of mixtures of $\mathrm{N}$-acryloyl (1S)-2,10-camphorsultam 2 with 1.5 equiv of $\mathrm{ZrCl}_{4}$ or $\mathrm{HfCl}_{4}$ were measured in $\mathrm{CDCl}_{3}$. The ${ }^{1} \mathrm{H}$ NMR spectra of compound $\mathbf{C}$ or $\mathbf{D}$ revealed downfield shifts of 0.1 to $1.1 \mathrm{ppm}$ for the neighboring protons of the chelation atoms (Table 3 , compound $\mathbf{C}$ or $\mathbf{D}$ ). The ${ }^{13} \mathrm{C}$ NMR spectra of compound $\mathbf{C}$ or $\mathbf{D}$ also revealed downfield shifts of 0.2 to 12.5 ppm for $\mathrm{C}(10), \mathrm{C}(2), \mathrm{C}(11)$ and $\mathrm{C}(13)$, whereas $\mathrm{C}(12)$ exhibited upfield shifts. Consequently, we concluded that $N$-acryloyl (1S)2,10-camphorsultam 2 formed metal complex with Lewis acids in solution.

Table 3 Comparison of NMR chemical shifts: non-coordinated (1S)-2 (A) and $\mathrm{N}$-acryloyl (1S)-2, 10-camphorsultam 2 coordinated with Lewis acid (B, C, D).

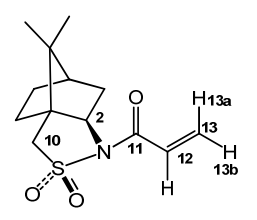

(1S)-2 $\mathbf{A}\left(\mathrm{CDCl}_{3}\right)$
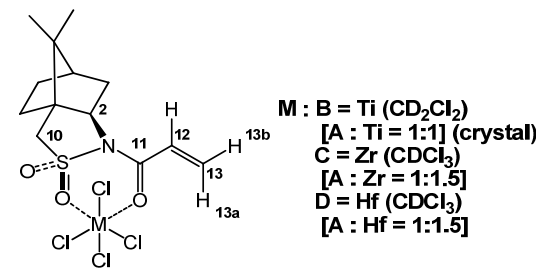

\begin{tabular}{|c|c|c|c|c|c|c|c|c|c|c|}
\hline \multirow{2}{*}{ compound } & \multicolumn{5}{|c|}{${ }^{1} \mathrm{H}-\mathrm{NMR}$ [ppm] $\left(270 \mathrm{MHz}, 25^{\circ} \mathrm{C}\right)$} & \multicolumn{5}{|c|}{${ }^{13} \mathrm{C}-\mathrm{NMR}$ [ppm] $\left(67.8 \mathrm{MHz}, 25^{\circ} \mathrm{C}\right)$} \\
\hline & (10) & (2) & (13a) & (13b) & (12) & (10) & (2) & (12) & (13) & (11) \\
\hline$A^{\text {a) }}$ & 3.50 & 3.95 & 5.86 & 6.51 & 6.78 & 53.04 & 65.05 & 127.69 & 131.31 & 163.75 \\
\hline $\begin{array}{l}\left.\mathrm{B}\left(\mathrm{TiCl}_{4}\right)^{\mathrm{b}}\right) \\
(\Delta: \mathrm{B}-\mathrm{A})\end{array}$ & $\begin{array}{c}3.70 \\
(+0.20)\end{array}$ & $\begin{array}{c}4.14 \\
(+0.19)\end{array}$ & $\begin{array}{c}6.25 \\
(+0.39)\end{array}$ & $\begin{array}{c}6.85 \\
(+0.34)\end{array}$ & $\begin{array}{c}6.70 \\
(-0.08)\end{array}$ & $\begin{array}{c}53.26 \\
(+0.22)\end{array}$ & $\begin{array}{c}66.26 \\
(+1.21)\end{array}$ & $\begin{array}{l}125.31 \\
(-2.38)\end{array}$ & - & - \\
\hline $\begin{array}{l}\mathrm{C}\left(\mathrm{ZrCl}_{4}\right)^{\mathrm{C}} \\
(\Delta: \mathrm{C}-\mathrm{A})\end{array}$ & $\begin{array}{c}3.67 \\
(+0.17)\end{array}$ & $\begin{array}{c}4.57 \\
(+0.62)\end{array}$ & $\begin{array}{c}6.53 \\
(+0.67) \\
\end{array}$ & $\begin{array}{c}7.54 \\
(+1.03)\end{array}$ & $\begin{array}{c}7.06 \\
(+0.28)\end{array}$ & $\begin{array}{r}53.31 \\
(+0.27)\end{array}$ & $\begin{array}{c}66.44 \\
(+1.39)\end{array}$ & $\begin{array}{l}123.53 \\
(-4.16)\end{array}$ & $\begin{array}{c}143.25 \\
(+11.94)\end{array}$ & $\begin{array}{l}171.33 \\
(+7.58)\end{array}$ \\
\hline $\begin{array}{l}\left.\mathrm{D}\left(\mathrm{HfCl}_{4}\right) \mathrm{c}\right) \\
(\Delta: \mathrm{D}-\mathrm{A})\end{array}$ & $\begin{array}{c}3.70 \\
(+0.20)\end{array}$ & $\begin{array}{c}4.58 \\
(+0.63)\end{array}$ & $\begin{array}{c}6.54 \\
(+0.68)\end{array}$ & $\begin{array}{c}7.63 \\
(+1.12)\end{array}$ & $\begin{array}{c}7.07 \\
(+0.29)\end{array}$ & $\begin{array}{c}53.40 \\
(+0.36)\end{array}$ & $\begin{array}{c}66.55 \\
(+1.50)\end{array}$ & $\begin{array}{l}123.26 \\
(-4.43)\end{array}$ & $\begin{array}{c}143.80 \\
(+12.49)\end{array}$ & $\begin{array}{l}171.72 \\
(+7.97)\end{array}$ \\
\hline
\end{tabular}

\section{Conclusion}

In conclusion, we have developed the highly diastereoselective Diels-Alder reaction of 1,2-dihydropyridine derivatives ( $\mathbf{1}$ and $\mathbf{4}$ ) with chiral dienophiles $\mathbf{2}$ which provide an efficient methodology for obtaining pharmacologically important chiral isoquinuclidines. Starting from $N$-acryloyl (1S)-2,10camphorsultam $(1 S)-2,(1 S, 4 R, 7 S)$-isoquinuclidines $((1 S)-3$ and $(1 S)-5)$ were obtained in good yield with excellent selectivity (up to $99 \%$ d.e.). On the other hand, starting from $N$-acryloyl $(1 R)$ 2,10-camphorsultam $(1 R)$-2, $(1 R, 4 S, 7 R)$-isoquinuclidines $((1 R)$ - 
3 and (1R)-5) were obtained (up to $99 \%$ d.e.). In the reaction, the chelation of Lewis acid with $N$-acryloyl (1S)-2,10camphorsultam 2 [or $N$-acryloyl (1R)-2,10-camphorsultam 2] is effective for affording the corresponding cycloaddition products.

\section{Experimental section}

\subsection{General information}

$(1 S)$-2,10-camphorsultam and (1R)-2,10-camphorsultam were purchased from Aldrich Chemical Co. Dichloromethane, tetrahydrofuran, methanol, ethanol, diethyl ether, toluene, pyridine, triethylamine, sodium hydride, sodium borohydride and copper chloride were purchased from Kanto Kagaku Reagent Division. Titanium tetrachloride, hafnium tetrachloride, tin tetrachloride, scandium trifluoromethanesulfonate, phenyl chloroformate, methyl chloroformate, $10 \%$ lithium methoxide in methanol solution, hexane, ethyl acetate, and chloroform were purchased from Wako Pure Chemical Ind. Dichlorotitanium diisopropoxide, acrylic acid, acryloyl chloride, 3-chloropropionyl chloride were purchased from Tokyo Chemical Ind. Co. Zirconium tetrachloride and molecular sieve 4A were purchased from Merck Co. IR spectra were recorded as thin films (liquids). ${ }^{1} \mathrm{H}$ NMR spectra and ${ }^{13} \mathrm{C}$ NMR spectra were recorded at 270 $\mathrm{MHz}$ and $67.8 \mathrm{MHz}$ on a JEOL JNM-EX 270 FT NMR SYSTEM in $\mathrm{CDCl}_{3}$ and DMSO- $\mathrm{d}_{6}$ using tetramethylsilane as internal standard. Specific rotations were recorded at the sodium $\mathrm{D}$ line with a polarimeter at room temperature. The diastereomeric excess (d.e.) of the cycloaddition products was determined by HPLC.

\subsection{General procedure}

Method A. General procedure for the cycloaddition of 1,2dyhydropyridines (1 or 4) and N-acryloyl 2,10-camphorsultams (2) with $\mathrm{TiCl}_{4}$.

To the solution of $\mathrm{N}$-acryloyl 2,10-camphorsultam $2(0.2 \mathrm{M}$, $269 \mathrm{mg}, 1 \mathrm{mmol})$, molecular sieves $4 \mathrm{~A}(100 \mathrm{mg})$ in dry $\mathrm{CH}_{2} \mathrm{Cl}_{2}$ $(5 \mathrm{~mL})$ was added $\mathrm{TiCl}_{4}$ (1.3 equiv.) at room temperature, and the yellow solution was stirred for $30 \mathrm{~min}$ under nitrogen. The solution was then cooled to $-78{ }^{\circ} \mathrm{C}$ by acetone-dry ice bath. When to the solution was added the solution of 1,2-dihydropyridine ( 1 or 4) $(0.4 \mathrm{M}, 2$ equiv. $)$ in dry $\mathrm{CH}_{2} \mathrm{Cl}_{2}(5 \mathrm{~mL})$ at $-78{ }^{\circ} \mathrm{C}$, the color of the solution changed from yellow to dark red. The solution was stirred at $-78{ }^{\circ} \mathrm{C}$ for $24 \mathrm{~h}$. The reaction was quenched by addition of $1 \mathrm{M} \mathrm{NaOH}$ (10 equiv.) and water and the product was extracted with chloroform. The organic solution was dried over sodium sulfate and filtered. After column chromatography of products on silica gel ( $20 \%$ ethyl acetate in hexane), the endo-3a and exo-3b were obtained.

Method B. General procedure for the cycloaddition of 1,2dyhydropyridines (1 or 4) and N-acryloyl 2,10-camphorsultams (2) with $\mathrm{ZrCl}_{4}$.

To the solution of $\mathrm{N}$-acryloyl 2,10-camphorsultam $2(0.2 \mathrm{M}, 1$ equiv.), molecular sieves $4 \mathrm{~A}(100 \mathrm{mg})$ in dry $\mathrm{CH}_{2} \mathrm{Cl}_{2}(5 \mathrm{~mL})$ was added $\mathrm{ZrCl}_{4}$ (2 equiv.) at room temperature and the solution was stirred for $20 \mathrm{~min}$ under nitrogen. Then the solution of 1,2dihydropyridiene (1 or 4$)\left(0.5 \mathrm{M}, 2.5\right.$ equiv.) in $\mathrm{CH}_{2} \mathrm{Cl}_{2}(5 \mathrm{~mL})$ was slowly added by a dropping funnel and the solution was stirred for $24 \mathrm{~h}$ under nitrogen at room temperature. The reaction was quenched by addition of $1 \mathrm{M} \mathrm{NaOH}$ (8 equiv.) and water and the product was extracted with chloroform. The organic solution was dried over sodium sulfate and filtered. After column chromatography of products on silica gel $(20 \%$ ethyl acetate in hexane), the endo-3a and exo-3b were obtained.

Method C. General procedure for the cycloaddition of 1,2dyhydropyridines (1 or 4) and N-acryloyl 2,10-camphorsultams (2) with $\mathrm{HfCl}_{4}$.

To the solution of $\mathrm{N}$-acryloyl 2,10-camphorsultam $2(0.2 \mathrm{M}, 1$ equiv.), molecular sieves $4 \mathrm{~A}(100 \mathrm{mg})$ in dry $\mathrm{CH}_{2} \mathrm{Cl}_{2}(5 \mathrm{~mL})$ was added $\mathrm{HfCl}_{4}$ (2 equiv.) at room temperature and the solution was stirred for $20 \mathrm{~min}$ under nitrogen. Then the solution of 1,2dihydropyridiene (1 or 4) $\left(0.5 \mathrm{M}, 2.5\right.$ equiv.) in $\mathrm{CH}_{2} \mathrm{Cl}_{2}(5 \mathrm{~mL})$ was added and the solution was stirred for $24 \mathrm{~h}$ under nitrogen at room temperature. The reaction was quenched by addition of 1 $\mathrm{M} \mathrm{NaOH}$ (8 equiv.) and water and the product was extracted with chloroform. The organic solution was dried over sodium sulfate and filtered. After column chromatography of products on silica gel (20\% ethyl acetate in hexane), the endo-3a and exo-3b were obtained.

Method D. General procedure for the cycloaddition of 1,2dyhydropyridines (1 or 4) and N-acryloyl 2,10-camphorsultams (2) under reflux.

The mixture of $N$-acryloyl (1S)-2,10-camphorsultam $2(0.1 \mathrm{M}$, $1 \mathrm{mmol}$ ) and 1-phenoxycarbpnyl 1,2-dihydropyridine 1 (3 mmol) was refluxed with stirring for $48 \mathrm{~h}$ in toluene $(10 \mathrm{~mL})$. The progress of the reaction was followed by TLC (33\% ethyl acetate in hexane). Once the reaction was completed, the solution was concentrated. The residue was purified by silica gel column chromatography (20\% ethyl acetate in hexane), and endo-3a and exo-3b were obtained.

(1S, 4R, 7S)-7-((1'S)-2,10-camphorsultam-4'-carbonyl)-2-azabicyclo[2.2.2]oct-5-ene-2-carboxylic acid phenyl ester (1S)-3a

The d.e. of endo-(1S)-3a was determined by HPLC analysis using a TOSOH TSK-GEL Silica-60; 1\% EtOH/hexane; flow rate, $1.0 \mathrm{ml} / \mathrm{min}$ : retention time, major $(1 S)$-3a $45 \mathrm{~min}$, minor diastereomer-3a 49 min. White solid. mp: $92-93{ }^{\circ} \mathrm{C} .{ }^{1} \mathrm{H}$ NMR (DMSO-d $\left.6,270 \mathrm{MHz}, 100{ }^{\circ} \mathrm{C}\right): \delta 0.94(3 \mathrm{H}, \mathrm{s}), 1.12(3 \mathrm{H}, \mathrm{s}), 1.16-$ $1.28(1 \mathrm{H}, \mathrm{m}), 1.35-1.47(1 \mathrm{H}, \mathrm{m}), 1.75-1.94(7 \mathrm{H}, \mathrm{m}), 2.93-2.96$ $(2 \mathrm{H}, \mathrm{m}), 3.35(1 \mathrm{H}$, br s$), 3.56-3.83(4 \mathrm{H}, \mathrm{m}), 5.12(1 \mathrm{H}$, br s$), 6.21-$ $6.26(1 \mathrm{H}, \mathrm{m}), 6.44-6.55(1 \mathrm{H}, \mathrm{m}), 7.09-7.19(3 \mathrm{H}, \mathrm{m}), 7.30-7.38$ $(2 \mathrm{H}, \mathrm{m}) ;{ }^{13} \mathrm{C}$ NMR (DMSO-d $\left.6,67.8 \mathrm{MHz}, 100{ }^{\circ} \mathrm{C}\right): \delta 18.97$ $\left(\mathrm{CH}_{3}\right), 19.89\left(\mathrm{CH}_{3}\right), 24.83,25.44,29.77,31.51,37.47,43.91$, $44.32,46.39,46.85,47.82,52.03,64.19,78.58,120.93$ (2C), 124.28, 128.11, 128.47 (2C), 135.27, 150.96, 151.70, 170.21. IR $(\mathrm{NaCl}) 1215,1338,1398,1454,1691,2962,3020 .[\alpha]_{\mathrm{D}}+14.2^{\circ}(c$ 1.0, $\left.\mathrm{CHCl}_{3}\right)\left(94 \%\right.$ d.e.). EI-MS m/z $470\left(\mathrm{M}^{+}\right), 377,334,201,162$, $135,107,79,69,55,41$. HRMS calcd for $\mathrm{C}_{25} \mathrm{H}_{30} \mathrm{~N}_{2} \mathrm{O}_{5} \mathrm{~S}(\mathrm{M}+)$ 470.1875, found 470.1875. Anal calcd for : C, 58.80; H, 6.91; N, 6.86. Found: C, 58.74; H, 7.14; N, 6.85 .

(1R, 4S, 7R)-7-((1'R)-2,10-camphorsultam-4'-carbonyl)-2-azabicyclo[2.2.2]oct-5-ene-2-carboxylic acid phenyl ester (1R)-3a

The d.e. of endo-( $1 R)$-3a was determined by HPLC analysis using a TOSOH TSK-GEL Silica-60; 1\% EtOH/hexane; flow rate, $1.0 \mathrm{ml} / \mathrm{min}$ : retention time, major $(1 R)-3 a 45 \mathrm{~min}$, minor diastereomer-3a 49 min. White solid. mp: 91-93 ${ }^{\circ} \mathrm{C} .{ }^{1} \mathrm{H}$ NMR (DMSO-d $\left.6,270 \mathrm{MHz}, 100{ }^{\circ} \mathrm{C}\right): \delta 0.94(3 \mathrm{H}, \mathrm{s}), 1.12(3 \mathrm{H}, \mathrm{s}), 1.16-$ $1.28(1 \mathrm{H}, \mathrm{m}), 1.35-1.47(1 \mathrm{H}, \mathrm{m}), 1.75-1.94(7 \mathrm{H}, \mathrm{m}), 2.93-2.96$ $(2 \mathrm{H}, \mathrm{m}), 3.35(1 \mathrm{H}$, br s$), 3.56-3.83(4 \mathrm{H}, \mathrm{m}), 5.12(1 \mathrm{H}$, br s $), 6.21-$ 
6.26 (1H, m), 6.44-6.55 (1H, m), 7.09-7.19 (3H, m), 7.30-7.38 $(2 \mathrm{H}, \mathrm{m}) ;{ }^{13} \mathrm{C}$ NMR (DMSO-d $\left.6,67.8 \mathrm{MHz}, 100{ }^{\circ} \mathrm{C}\right): \delta 18.97$ $\left(\mathrm{CH}_{3}\right), 19.89\left(\mathrm{CH}_{3}\right), 24.83,25.44,29.77,31.51,37.47,43.91$, $44.32,46.39,46.85,47.82,52.03,64.19,78.58,120.93$ (2C), $124.28,128.11,128.47$ (2C), 135.27, 150.96, 151.70, 170.21. IR $(\mathrm{NaCl}) 1215,1338,1398,1454,1691,2962,3020 .[\alpha]_{\mathrm{D}}-12.7^{\circ}(c$ $\left.1.0, \mathrm{CHCl}_{3}\right)(96 \%$ d.e. $)$.

$(1 S, 4 R, 7 S)-7-((1 ' S)-2,10-c a m p h o r s u l t a m-4 '-c a r b o n y l)-2-a z a-$ bicyclo[2.2.2]oct-5-ene-2-carboxylic acid methyl ester (1S)-5a

The d.e. of endo-(1S)-5a was determined by HPLC analysis using a TOSOH TSK-GEL Silica-60; 1\% EtOH/hexane; flow rate, $1.0 \mathrm{ml} / \mathrm{min}$ : retention time, major (1S)-5a $60 \mathrm{~min}$, minor diastereomer-5a $63 \mathrm{~min}$. White solid, mp: $204-205{ }^{\circ} \mathrm{C}$. ${ }^{1} \mathrm{H}$ NMR $\left(\mathrm{CDCl}_{3}, 270 \mathrm{MHz}, 25^{\circ} \mathrm{C}\right): \delta 0.97(3 \mathrm{H}, \mathrm{s}) 1.21(3 \mathrm{H}, \mathrm{s}), 1.30-1.45$ $(2 \mathrm{H}, \mathrm{m}), 1.84-2.06(7 \mathrm{H}, \mathrm{m}), 2.86-2.94(2 \mathrm{H}, \mathrm{m}), 3.24-3.28(1 \mathrm{H}$, $\mathrm{m}), 3.38-3.54(2 \mathrm{H}, \mathrm{m}), 3.67-3.75(4 \mathrm{H}, \mathrm{m}), 3.82(1 \mathrm{H}, \mathrm{br} \mathrm{s}), 5.03-$ $5.17(1 \mathrm{H}, \mathrm{m}), 6.18-6.29(1 \mathrm{H}, \mathrm{m}), 6.44-6.50(1 \mathrm{H}, \mathrm{m}) ;{ }^{13} \mathrm{C} \mathrm{NMR}$ $\left(\mathrm{CDCl}_{3}, 67.8 \mathrm{MHz}, 25{ }^{\circ} \mathrm{C}\right): \delta 19.77\left(\mathrm{CH}_{3}\right), 20.65\left(\mathrm{CH}_{3}\right), 25.82$, $26.42,30.82,32.60,38.30,44.35,45.10,46.50,46.95,47.76$, $48.39,52.31,52.81,65.08,129.76,134.77,155.43,171.49$. IR $(\mathrm{NaCl}) 1215,1338,1398,1454,1691,2962,3020 .[\alpha]_{\mathrm{D}}-38.8^{\circ}(c$ $\left.1.0, \mathrm{CHCl}_{3}\right)(99 \%$ d.e. $)$. EI-MS m/z $408\left(\mathrm{M}^{+}\right), 377,334,270,194$, $165,139,124,94,55,41$; HRMS calcd for $\mathrm{C}_{20} \mathrm{H}_{28} \mathrm{~N}_{2} \mathrm{O}_{5} \mathrm{~S}(\mathrm{M}+)$ 408.1719, found 408.1703. Anal calcd for : C, 63.81; H, 6.43; N, 5.95. Found: C, 63.61; H, 6.71; N, 5.78.

(1R, 4S, 7R)-7-((1'R)-2,10-camphorsultam-4'-carbonyl)-2-azabicyclo[2.2.2]oct-5-ene-2-carboxylic acid methyl ester (1R)-5a

The d.e. of endo-(1R)-5a was determined by HPLC analysis using a TOSOH TSK-GEL Silica-60; 1\% EtOH/hexane; flow rate, $1.0 \mathrm{ml} / \mathrm{min}$ : retention time, major $(1 R)-5 a \quad 60 \mathrm{~min}$, minor (1S)-5a 63 min. White solid, mp: 203-204 ${ }^{\circ} \mathrm{C} .{ }^{1} \mathrm{H}$ NMR $\left(\mathrm{CDCl}_{3}\right.$, $\left.270 \mathrm{MHz}, 25^{\circ} \mathrm{C}\right): \delta 0.97(3 \mathrm{H}, \mathrm{s}) 1.21(3 \mathrm{H}, \mathrm{s}), 1.30-1.45(2 \mathrm{H}, \mathrm{m})$, 1.84-2.06 (7H, m), 2.86-2.94 $(2 \mathrm{H}, \mathrm{m}), 3.24-3.28(1 \mathrm{H}, \mathrm{m}), 3.38-$ $3.54(2 \mathrm{H}, \mathrm{m}), 3.67-3.75(4 \mathrm{H}, \mathrm{m}), 3.82(1 \mathrm{H}, \mathrm{br} \mathrm{s}), 5.03-5.17(1 \mathrm{H}$, $\mathrm{m})$, 6.18-6.29 $(1 \mathrm{H}, \mathrm{m}), 6.44-6.50(1 \mathrm{H}, \mathrm{m}) ;{ }^{13} \mathrm{C} \mathrm{NMR}\left(\mathrm{CDCl}_{3}\right.$, $\left.67.8 \mathrm{MHz}, 25{ }^{\circ} \mathrm{C}\right): \delta 19.77\left(\mathrm{CH}_{3}\right), 20.65\left(\mathrm{CH}_{3}\right), 25.82,26.42$, $30.82,32.60,38.30,44.35,45.10,46.50,46.95,47.76,48.39$, $52.31,52.81,65.08,129.76,134.77,155.43,171.49 . \mathrm{IR}(\mathrm{NaCl})$ $1215,1338,1398,1454,1691,2962,3020 .[\alpha]_{\mathrm{D}}+39.8^{\circ}(c 1.0$, $\left.\mathrm{CHCl}_{3}\right)(99 \%$ d.e. $)$.

\section{Ester exchange reaction of $5 a$}

The solution of $10 \%$ LiOMe-MeOH $(570 \mathrm{mg}, 1.5 \mathrm{mmol})$ in $\mathrm{MeOH}(5 \mathrm{~mL})$ was cooled at $0{ }^{\circ} \mathrm{C}$. To the solution was added the solution of endo (1S)-5a (204 mg, $0.5 \mathrm{mmol})$ in THF (2 mL), and the mixture was stirred at $0{ }^{\circ} \mathrm{C}$ for $4 \mathrm{~h}$. The reaction was quenched by addition of saturated ammonium chloride, and the product was extracted with chloroform. The organic solution was dried over sodium sulfate and filtered. After removal of solvent, the residue was purified by column chromatography on silica gel $(10 \% \mathrm{MeOH}$ in chloroform $)$ to give product $(1 S, 4 R, 7 S)-6$ as colorless oil.

(1S, 4R, 7S)-2-methoxycarbonyl-2-azabicyclo[2.2.2]oct-5-ene-7methyl carboxylate (7S)-6

Ester exchange reaction was carried out to give (7S)-6 as colorless oil in $54 \%$ yield. ${ }^{1} \mathrm{H}$ NMR $\left(\mathrm{CDCl}_{3}, 270 \mathrm{MHz}, 25^{\circ} \mathrm{C}\right): \delta$ 1.85-1.87 (2H, m), 2.83 (1H, br s), 2.90-2.98 (1H, m) 3.06-3.12
(1H, m), 3.24-3.39 (1H, m), 3.64-3.72 (6H, m), 4.90-5.17 $(1 \mathrm{H}$, $\mathrm{m}), 6.28-6.48(2 \mathrm{H}, \mathrm{m}) ;{ }^{13} \mathrm{C} \mathrm{NMR}\left(\mathrm{CDCl}_{3}, 67.8 \mathrm{MHz}, 25{ }^{\circ} \mathrm{C}\right): \delta$ 25.85, 30.46, 43.58, 46.89, 47.19, 51.85, 52.40, 130.45, 135.00, 155.83, 173.10. $[\alpha]_{\mathrm{D}}+116^{\circ}\left(c 0.6, \mathrm{CHCl}_{3}\right)$; lit. $^{11}[\alpha]_{\mathrm{D}}+109^{\circ}(c 1$, $\left.\mathrm{CHCl}_{3}\right)$.

(1R, 4S, 7R)-2-methoxycarbonyl-2-azabicyclo[2.2.2]oct-5-ene7-methyl carboxylate (7R)-6

Ester exchange reaction of (1R)-5a was carried out to give (7R)-6 as colorless oil in $49 \%$ yield. ${ }^{1} \mathrm{H}$ NMR $\left(\mathrm{CDCl}_{3}, 270 \mathrm{MHz}\right.$, $\left.25{ }^{\circ} \mathrm{C}\right): \delta 1.85-1.87(2 \mathrm{H}, \mathrm{m}), 2.83(1 \mathrm{H}, \mathrm{br} \mathrm{s}), 2.90-2.98(1 \mathrm{H}, \mathrm{m})$ 3.06-3.12 (1H, m), 3.24-3.39 (1H, m), 3.64-3.72 (6H, m), 4.90$5.17(1 \mathrm{H}, \mathrm{m}), 6.28-6.48(2 \mathrm{H}, \mathrm{m}) ;{ }^{13} \mathrm{C} \mathrm{NMR}\left(\mathrm{CDCl}_{3}, 67.8 \mathrm{MHz}\right.$, $\left.25^{\circ} \mathrm{C}\right): \delta 25.85,30.46,43.58,46.89,47.19,51.85,52.40,130.45$, $135.00,155.83,173.10 .[\alpha]_{\mathrm{D}}-98^{\circ}\left(c 0.6, \mathrm{CHCl}_{3}\right) ;$ lit. $^{11}[\alpha]_{\mathrm{D}}-110^{\circ}$ (c $1, \mathrm{CHCl}_{3}$ ).

\section{Preparation of $\mathrm{N}$-acryloyl 2,10-camphorsultam $2^{9}$}

To the solution of acrylic acid (1.3 equiv.) and triethylamine (2.5 equiv.) in THF (volume corresponded to $0.2 \mathrm{M}$ of 2,10camphorsultam) was added acryloyl chloride (1.2 equiv.) at -20 ${ }^{\circ} \mathrm{C}$. A white solid was formed instantaneously. The mixture was stirred at $-20{ }^{\circ} \mathrm{C}$ for $1 \mathrm{~h}$. Lithium chloride (1.1 equiv.) was added, followed by 2,10-camphorsultam $(5.0 \mathrm{~g}, 23.2 \mathrm{mmol})$. The mixture was allowed to warm to room temperature and stirred for $48 \mathrm{~h}$. The reaction was quenched by addition of $0.2 \mathrm{M} \mathrm{HCl} \mathrm{(2}$ equiv.), and THF was removed in vacuo. The residue was partitioned between ethyl acetate and $0.2 \mathrm{M} \mathrm{HCl}$ ( 0.5 equiv.). The organic layer was washed subsequently with $0.2 \mathrm{M} \mathrm{HCl}$, brine, $1 \mathrm{M}$ sodium bicarbonate (2 times), and brine. The organic solution was then dried over sodium sulfate and filtered. Ethyl acetate was removed in vacuo, and the residue was dissolved in toluene. The toluene solution was filtered through a silica gel bed, and the cake was washed with toluene. Concentration of toluene solution to dryness afforded the $N$-acryloyl 2,10-camphorsultam 2 which was crystallized from hexane as a white crystalline solid.

\section{N-acryloyl (1S)-2,10-camphorsultam 2}

White solid (recrystallized from hexane), 84\% yield, mp: 192$195{ }^{\circ} \mathrm{C}$; lit. ${ }^{12 \mathrm{a})} \mathrm{mp}: 191-193{ }^{\circ} \mathrm{C}$. $[\alpha]_{\mathrm{D}}-102^{\circ}$ (c 1.0, $\left.\mathrm{CHCl}_{3}\right)$; lit. ${ }^{9 \mathrm{a})}$ $[\alpha]_{\mathrm{D}}-100.9^{\circ}\left(c 0.983, \mathrm{CHCl}_{3}\right) .{ }^{1} \mathrm{H}$ NMR $[\mathrm{ppm}]\left(270 \mathrm{MHz}, \mathrm{CDCl}_{3}\right.$, $\left.25^{\circ} \mathrm{C}\right): \delta 0.98(3 \mathrm{H}, \mathrm{s}), 1.18(3 \mathrm{H}, \mathrm{s}), 1.47-1.33(2 \mathrm{H}, \mathrm{m}), 1.99-1.89$ $(3 \mathrm{H}, \mathrm{m}), 2.14-2.06(2 \mathrm{H}, \mathrm{m}), 3.49(2 \mathrm{H}, \mathrm{q}, J=21.6,13.8 \mathrm{~Hz}), 3.94$ $(1 \mathrm{H}, \mathrm{t}, J=6.4 \mathrm{~Hz}), 5.86(1 \mathrm{H}, \mathrm{dd}, J=10.9,1.5 \mathrm{~Hz}), 6.50(1 \mathrm{H}, \mathrm{dd}$, $J=16.7,1.5 \mathrm{~Hz}), 6.87(1 \mathrm{H}, \mathrm{dd}, J=16.7,10.4 \mathrm{~Hz}) .{ }^{13} \mathrm{C} \mathrm{NMR}$ [ppm] $\left(67.8 \mathrm{MHz}, \mathrm{CDCl}_{3}, 2{ }^{\circ} \mathrm{C}\right): \delta 19.86,20.85,26.47,32.86$, $38.40,44.67,47.80,48.56,53.10,65.11,127.74,131.39,163.82$.

\section{$N$-acryloyl (1R)-2,10-camphorsultam 2}

White solid (recrystallized from hexane), 74\% yield, mp: 196$198{ }^{\circ} \mathrm{C} .[\alpha]_{\mathrm{D}}+104^{\circ}\left(c 1.0, \mathrm{CHCl}_{3}\right)$ lit. $\left.{ }^{9 b}\right)[\alpha]_{\mathrm{D}}+102^{\circ}(c$ 1.7, $\left.\mathrm{CHCl}_{3}\right) .{ }^{1} \mathrm{H}$ NMR $[\mathrm{ppm}]\left(270 \mathrm{MHz}, \mathrm{CDCl}_{3}, 25{ }^{\circ} \mathrm{C}\right): \delta 0.98(3 \mathrm{H}$, s), $1.18(3 \mathrm{H}, \mathrm{s}), 1.47-1.33(2 \mathrm{H}, \mathrm{m}), 1.99-1.89(3 \mathrm{H}, \mathrm{m}), 2.14-2.06$ $(2 \mathrm{H}, \mathrm{m}), 3.49(2 \mathrm{H}, \mathrm{q}, J=21.6,13.8 \mathrm{~Hz}), 3.94(1 \mathrm{H}, \mathrm{t}, J=6.4 \mathrm{~Hz})$, $5.86(1 \mathrm{H}, \mathrm{dd}, J=10.9,1.5 \mathrm{~Hz}), 6.50(1 \mathrm{H}, \mathrm{dd}, J=16.7,1.5 \mathrm{~Hz})$, $6.87(1 \mathrm{H}, \mathrm{dd}, J=16.7,10.4 \mathrm{~Hz}) .{ }^{13} \mathrm{C}$ NMR $[\mathrm{ppm}](67.8 \mathrm{MHz}$, $\left.\mathrm{CDCl}_{3}, 25{ }^{\circ} \mathrm{C}\right): \delta 19.86,20.85,26.47,32.86,38.40,44.67,47.80$, $48.56,53.10,65.11,127.74,131.39,163.82$.

Preparation of 1-phenoxycarbonyl-1,2-dihydropyridine $1^{8}$ 
Pyridine $(24.0 \mathrm{~g}, 303 \mathrm{mmol})$ and $\mathrm{NaBH}_{4}(6.0 \mathrm{~g}, 159 \mathrm{mmol})$ were stirred together at $-78{ }^{\circ} \mathrm{C}$ in ethanol $(180 \mathrm{~mL})$, and then phenyl chloroformate $(32.0 \mathrm{~g}, 204 \mathrm{mmol})$ was added slowly to the solution by a dropping funnel for $1 \mathrm{~h}$. The mixture was stirred at $-78{ }^{\circ} \mathrm{C}$ for $24 \mathrm{~h}$. The solution was poured into ice-water, and the mixture was stirred until the $\mathrm{H}_{2}$ bubble stopped. The mixture was extracted with diethyl ether $(100 \mathrm{~mL} \times 3)$ and the ether solution was dried over sodium sulfate. The organic layer was filtered and the diethyl ether removed in vacuo. The residue was recrystallized from ethanol to give the product $\mathbf{1}$ as a white solid in $67 \%$ yield $(27.50 \mathrm{~g}, 136.7 \mathrm{mmol})$. The ratio of 1,2dihydropyridine and 1,4-dihydropyridine was 93 to 7. mp: 64-66 ${ }^{\circ} \mathrm{C} .{ }^{1} \mathrm{H}$ NMR $[\mathrm{ppm}]\left(270 \mathrm{MHz}, \mathrm{CDCl}_{3}, 25{ }^{\circ} \mathrm{C}\right): \delta 4.45(1 \mathrm{H}, \mathrm{q}, J=$ $3.8,2.0 \mathrm{~Hz}), 4.59(1 \mathrm{H}, \mathrm{br} \mathrm{s}), 5.31-5.22(1 \mathrm{H}, \mathrm{m}), 5.62-5.59(1 \mathrm{H}$, $\mathrm{m}), 5.93-5.88(1 \mathrm{H}, \mathrm{m}), 6.84(1 \mathrm{H}, \mathrm{dd}, J=20.0,7.7 \mathrm{~Hz}), 7.13(2 \mathrm{H}$, $\mathrm{d}, J=7.6), 7.22(1 \mathrm{H}, \mathrm{t}, J=8.2 \mathrm{~Hz}), 7.38(2 \mathrm{H}, \mathrm{t}, J=7.8 \mathrm{~Hz}) ;{ }^{13} \mathrm{C}$ NMR $\left(\mathrm{CDCl}_{3}, 67.8 \mathrm{MHz}, 25{ }^{\circ} \mathrm{C}\right): \delta \quad 43.78,105.82,119.47$, 121.54 (2C), 121.82, 125.35, 125.67, 126.06, 129.36 (2C), 150.81 .

\section{Preparation of 1-methoxycarbonyl-1,2-dihydropyridine $4^{8}$}

Pyridine (4.74 g, $60 \mathrm{mmol})$ and $\mathrm{NaBH}_{4}(2.60 \mathrm{~g}, 68 \mathrm{mmol})$ were stirred in ethanol $(50 \mathrm{~mL})$ at $-78{ }^{\circ} \mathrm{C}$, and then methyl chloroformate $(5.68 \mathrm{~g}, 60 \mathrm{mmol})$ was added slowly to the solution by a dropping funnel for $1 \mathrm{~h}$. The mixture was stirred at $-78{ }^{\circ} \mathrm{C}$ for $24 \mathrm{~h}$. The solution was poured into ice-water, and the mixture was stirred until the $\mathrm{H}_{2}$ bubble stopped. The mixture was extracted with diethyl ether $(100 \mathrm{~mL} \times 3)$ and the ether solution was dried over sodium sulfate. The organic layer was filtered and the diethyl ether removed in vacuo. The product was purified by column chromatography on silica gel $(10 \%$ ethyl acetate in hexane) to give the product 1 as a colorless oil in $98 \%(8.18 \mathrm{~g}$, $58.8 \mathrm{mmol})$. The ratio of 1,2-dihydropyridine and 1,4dihydropyridine was 94 to $6 .{ }^{1} \mathrm{H}$ NMR [ppm] $\left(270 \mathrm{MHz}, \mathrm{CDCl}_{3}\right.$, $\left.25{ }^{\circ} \mathrm{C}\right): \delta 3.78(3 \mathrm{H}, \mathrm{s}), 4.27-4.16(1 \mathrm{H}, \mathrm{m}), 4.36(1 \mathrm{H}, \mathrm{br} \mathrm{s}), 5.14-$ $5.12(1 \mathrm{H}, \mathrm{m}), 5.52-5.51(1 \mathrm{H}, \mathrm{m}), 5.86-5.81(1 \mathrm{H}, \mathrm{m}), 6.66-6.63$ $(1 \mathrm{H}, \mathrm{m}) ;{ }^{13} \mathrm{C} \mathrm{NMR}\left(\mathrm{CDCl}_{3}, 67.8 \mathrm{MHz}, 25{ }^{\circ} \mathrm{C}\right) \delta 43.35,52.91$, $104.61,118.91,121.73,125.41,149.57$.

\section{Preparation of N-3-chloropropanoyl (1S)-2,10-camphor sultam $^{12}$}

To a suspention of $\mathrm{NaH}(38.5 \mathrm{mg}, 1.6 \mathrm{mmol})$ and toluene (5 $\mathrm{mL})$ was added $(1 S)$ - 2,10-camphorsultam $(215 \mathrm{mg}, 1 \mathrm{mmol})$. After $1 \mathrm{~h}$ at room temperature, $\mathrm{CuCl}(13 \mathrm{mg}, 0.13 \mathrm{mmol})$ was added. This mixture was added to a solution of 3-chloropropionyl chloride in toluene $(2 \mathrm{~mL})$. After $30 \mathrm{~min}$, the reaction mixture was quenched with water and extracted with EtOAc. The extract was passed through silica gel, concentrated under reduced pressure, and purified by column chromatography on silica gel (20\% ethyl acetate in Hrxane) to yield $N$-3-chloropropanoyl (1S)2,10-camphorsultam in $53 \%$ yield $(161 \mathrm{mg}, 0.53 \mathrm{mmol}) . \mathrm{mp}$ : $134 \sim 135{ }^{\circ} \mathrm{C},[\alpha]_{\mathrm{D}}-98.7^{\circ}$ (c 1.0, $\left.\mathrm{CHCl}_{3}\right) .{ }^{1} \mathrm{H}$ NMR [ppm] $(270$ $\left.\mathrm{MHz}, \mathrm{CDCl}_{3}, 25^{\circ} \mathrm{C}\right): \delta 0.98(3 \mathrm{H}, \mathrm{s}), 1.16(3 \mathrm{H}, \mathrm{s}), 1.32-1.46(2 \mathrm{H}$, $\mathrm{m}), 1.89(4 \mathrm{H}, \mathrm{br}-\mathrm{s}), 2.04-2.14(2 \mathrm{H}, \mathrm{m}), 3.10-3.31(2 \mathrm{H}, \mathrm{m}), 3.49$ $(2 \mathrm{H}, \mathrm{q}, J=21.8,13.9), 3.74-3.97(2 \mathrm{H}, \mathrm{m}) ;{ }^{13} \mathrm{C} \mathrm{NMR}\left(\mathrm{CDCl}_{3}\right.$, $\left.67.8 \mathrm{MHz}, 25{ }^{\circ} \mathrm{C}\right) \delta 19.80,20.70,26.35,32.71,38.24,38.34$, $44.54,47.74,48.56,52.80,53.02,65.11,168.37$.

\section{Preparation of the crystalline complex of (1S)-2 with $\mathrm{TiCl}_{4}{ }^{14}$}

$N$-acryloyl (1S)-2,10-camphorsultam 2 (269 mg, $1 \mathrm{mmol}$ ) was dissolved in $\mathrm{CH}_{2} \mathrm{Cl}_{2}(10 \mathrm{~mL})$ in one of two two-necked flasks which were linked by glass tube. Addition of $\mathrm{TiCl}_{4}(0.12 \mathrm{~mL}, 1$ mmol) to the solution at $\mathrm{rt}$ gave a clear yellow solution. Hexane $(10 \mathrm{~mL})$ was placed in the other flask which was then closed with septum and allowed to stand at $\mathrm{rt}$ for several days. Slow diffusion of the solvents resulted in the formation of fine yellow crystals of the complex of $(1 S)-2$ with $\mathrm{TiCl}_{4}$. The crystal is very moisture sensitive and easily decomposed for few minutes in the air. The ${ }^{1} \mathrm{H}$ and ${ }^{13} \mathrm{C}-\mathrm{NMR}$ spectra were measured and the results were listed in Table 4. ${ }^{1} \mathrm{H}$ NMR [ppm] $\left(270 \mathrm{MHz}, \mathrm{CD}_{2} \mathrm{Cl}_{2}, 25{ }^{\circ} \mathrm{C}\right): \delta$ $1.01(3 \mathrm{H}, \mathrm{s}), 1.16(3 \mathrm{H}, \mathrm{s}), 1.36-1.56(2 \mathrm{H}, \mathrm{m}), 1.99(3 \mathrm{H}, \mathrm{br}-\mathrm{s})$, 2.23-2.26 (2H, m), $3.70(2 \mathrm{H}$, br-s), $4.14(1 \mathrm{H}$, br-s), $6.25(1 \mathrm{H}, \mathrm{br}-$ $\mathrm{s}), 6.64-6.73(1 \mathrm{H}, \mathrm{m}), 6.82-6.87(1 \mathrm{H}, \mathrm{m}) ;{ }^{13} \mathrm{C} \mathrm{NMR}\left(\mathrm{CD}_{2} \mathrm{Cl}_{2}, 67.8\right.$ $\left.\mathrm{MHz}, 25^{\circ} \mathrm{C}\right) \delta 19.93,21.17,26.41,33.15,38.85,45.40,48.34$, $48.61,53.26,66.26,125.31$ (Two signals of C(13) and C(11) were not observed).

\section{References and notes}

1 a) Kuehne, M. E.; Marko, I. Syntheses of Vinblastine-type Alkaloids. In The Alkaloids. Antitumor Bisindole Alkaloids from Catharanthus roseus (L.); Brossi A.; Suffness M. Eds.; Academic Press: San Diego, 1990; Vol. 37, pp. 77131. b) Popik, P.; Skolnick, P. Pharmacology of Ibogaine and Ibogaine-related Alkaloids. In The Alkaloids. Chemistry and Biology; G. A. Cordell, Ed., Academic Press: San Diego, 1999; Vol 52, pp. 197-231. c) Khana, M. O. F.; Levid, M. S.; Clarkc, C. R.; Ablordeppeya, S. Y.; Lawd, S.-J.; Wilsone, N. H.; Bornef, R. F. Studies in Natural Products Chemistry, 2008; Vol. 34, pp. 753-787.

2 a) Nakano, H.; Tsugawa, N.; Takahashi, K.; Okuyama, Y.; Fujita, R. Tetrahedron 2006, 62, 10879. b) He, D. Y.; McGough, N. N.; Ravindranathan, A.; Jeanblanc, J.; Logrip, M. L.; Phamluong, K.; Janak, P. H.; Pon, D. J. Neurosci. 2005, 25, 619.

3 Martin, S. F.; Rueger, H.; Williamson, S. A.; Grzejszczak, S. J. Am. Chem. Soc. 1987, 109, 6124.

4 Satoh, N.; Akiba, T.; Yokoshima, S.; Fukuyama, T. Tetrahedron, 2009, 65, 3239.

5 Krow, G. R.; Cheung, O. H.; Hu, Z.; Huang, Q.; Hutchinson, J.; Liu, N.; Nguyen, K. T.; Ulrich, S.; Yuan, J.; Xiao, Y.; Wypij, D. M.; Zuo, F.; Carroll, P. J. Tetrahedron 1999, 55, 7747.

6 a) Matsumura, Y.; Nakamura, Y.; Maki, T.; Onomura, O. Tetrahedron Lett. 2000, 41, 7685. b) dos Santos, D. C.; de Freitas Gil, R. P.; Gil, L.; Marazano, C. Tetrahedron Lett. 2001, 42, 6109. c) Ho, G.-J.; Mather, D. J. J. Org. Chem. 1995, 60, 2271. d) Marazano, C.; Yannic, Y.; Mehmandoust, M.; Das, B, C. Tetrahedron Lett. 1990, 31, 1995. e) Kouklovsky C.; Pouihes A.; Langlois Y. J. Am. Chem. Soc. 1990, 112, 6672.

7 a) Pd-POZ catalyst; Nakano, H.; Tsugawa, N.; Takahashi, K.; Okuyama, Y.; Fujita, R. Tetrahedron 2006, 62, 10879. b) $\mathrm{Cr}^{\mathrm{III}}$ salen complex catalyst; Takenaka, N.; Huang, Y.; Rawal, V. H. Tetrahedron 2002, 58, 8299.

8 Fowler, F. W. J. Org. Chem. 1972, 37, 1321.

9 a) Ho, G.-J.; Mathre, D. J. J. Org. Chem. 1995, 60, 2271; b) Thom, C.; Kocieński, P. Synthesis, 1992, 582.

10 Hirama, M.; Kato, Y.; Seki, C.; Matsuyama, H.; Oshikiri, N.; Iyoda, M. Chem. Lett., 2008, 37, 924.

11 Mehmandoust, M.; Marazano, C.; Singh, R.; Gillet, B.; Césario, M.; Fourrey, J.-L.; Das, B. C. Tetrahedron Lett. 1988, 29, 4423. 
12 a) Kim, B. H.; Lee, J. Y. Tetrahedron: Asymmetry, 1991, 2, 1359; b) Curran, D. P.; Heffner, T.A. J. Org. Chem. 1990, $55,4585$.

13 Cycloaddition of 1-tert-butoxycarbonyl 1,2dihydropyridine with (1S)-2 has been reported; Campbell,
M. M.; Sainsbury, M.; Searle, P. A.; Davies, G. M. Tetrahedron Lett. 1992, 33, 3181.

14 The X-ray analysis of the $\mathrm{TiCl}_{4}$-complex of $\mathrm{N}$-crotonoyl (1S)-2,10-camphorsultam has been reported; Oppolzer, W.; Rodriguez, I.; Blagg, J.; Bernardinelli, G. Helv. Chim. Acta 1989, 72, 123. 